\title{
Article/Artigo
}

\section{Bacterial meningitis and living conditions}

\author{
Meningites bacterianas e condições de vida
}

\author{
Shirley Fonseca de Souza ${ }^{1,}$ Maria da Conceição Nascimento Costa ${ }^{2}$, Jairnilson Silva Paim ${ }^{2}$, Marcio Santos \\ da Natividade ${ }^{2}$, Susan Martins Pereira ${ }^{2}$, Alcina Marta de Souza Andrade ${ }^{1}$ and Maria Glória Teixeira ${ }^{2}$
}

\begin{abstract}
Introduction: Bacterial meningitis has great social relevance due to its ability to produce sequelae and cause death. It is most frequently found in developing countries, especially among children. Meningococcal meningitis occurs at a high frequency in populations with poor living conditions. This study describes the temporal evolution of bacterial meningitis in Salvador, Brazil, 1995-2009, and verifies the association between its spatial variation and the living conditions of the population. Methods: This was an ecological study in which the areas of information were classified by an index of living conditions. It examined fluctuations using a trend curve, and the relationship between this index and the spatial distribution of meningitis was verified using simple linear regression. Results: From 1995-2009, there were 3,456 confirmed cases of bacterial meningitis in Salvador. We observed a downward trend during this period, with a yearly incidence of 9.1 cases/100,000 population and fatality of $16.7 \%$. Children aged $<5$ years old and male were more affected. There was no significant spatial autocorrelation or pattern in the spatial distribution of the disease. The areas with the worst living conditions had higher fatality from meningococcal disease $(\beta=0.0078117$, $\mathrm{p}<0.005)$. Conclusions: Bacterial meningitis reaches all social strata; however, areas with poor living conditions have a greater proportion of cases that progress to death. This finding reflects the difficulties for ready access and poor quality of medical care faced by these populations.
\end{abstract}

Keywords: Bacterial meningitis. Meningococcal disease. Living conditions. Time trend. Spatial distribution.

\section{RESUMO}

Introdução: As meningites bacterianas apresentam grande relevância social, devido à sua capacidade de produzir sequelas e mortes. Ocorrem mais frequentemente nos países em desenvolvimento, especialmente entre crianças. Meningite meningocócica ocorre com maior intensidade em populações de baixas condições de vida. Este estudo descreve a evolução temporal das meningites bacterianas em Salvador, 1995-2009, e verifica a associação entre sua variação espacial e condições de vida da população. Métodos: Realizou-se um estudo ecológico no qual as zonas de informação foram classificadas por um índice de condições de vida. Foram examinadas flutuações nas curvas de tendência, e a relação entre este índice e a distribuição espacial das meningites foi verificada por meio de regressão linear simples. Resultados: De 1995 a 2009 foram confirmados, em Salvador, 3.456 casos de meningites bacterianas. Observouse no período uma tendência descendente, incidência anual de 9,1/100.000 e letalidade de $16,7 \%$. Crianças menores de cinco anos de idade e do sexo masculino foram mais afetadas. Não houve autocorrelação espacial significativa ou padrão na distribuição espacial da doença. Áreas com piores condições de vida apresentaram maior letalidade da doença meningocócica $(\beta=0,0078117, p<0,005)$. Conclusões: As meningites bacterianas atingem todos os estratos sociais, no entanto em áreas onde a população é menos favorecida encontra-se maior proporção de casos que evoluem para a morte. Este achado reflete as dificuldades para pronto acesso e a má qualidade dos cuidados médicos enfrentadas por essas populações.

Palavras-chaves: Meningites bacterianas. Doença meningocócica. Condições de vida. Tendência temporal. Distribuição espacial.

1. Secretaria de Saúde do Estado da Bahia. Salvador, BA. 2. Instituto de Saúde Coletiva, Universidade Federal da Bahia, Salvador, BA.

Address to: Dra. Maria Glória Teixeira. ISC/UFBA. Rua Basílio da Gama s/n, Canela, 40110-040 Salvador, BA, Brasil.

Phone: 5571 3283-7445

e-mail:magloria@ufba.br

Received in 01/07/2011

Accepted in 22/09/2011

\section{INTRODUCTION}

Meningitis refers to a group of infectious diseases of great social relevance, particularly taking into account the high fatality rates and sequelae that may occur when the membranes that envelop the brain are invaded by certain etiological agents. These diseases are included in the top 10 causes of death by infectious diseases worldwide, especially in developing countries ${ }^{1}$.

The occurrence of bacterial meningitis varies greatly between and within regions, countries, states, and municipalities, both in relation to the age groups most affected and to the frequency of the most prevalent etiological agents, principally following the inclusion of conjugate vaccines in the basic immunization schedule for children ${ }^{2-5}$. It should be emphasized, therefore, that the available scientific literature on the incidence and lethality of these forms of meningitis generally involve different age groups and/or only the main etiological agents or, sometimes, may refer to specific healthcare services, making comparisons difficult.

Most forms of bacterial meningitis that occur following the neonatal period are caused by Haemophilus influenzae type b (Hib), Neisseria meningitidis, or Streptococcus pneumoniae ${ }^{6}$. The last 2 are the predominant etiological agents in countries where the Hib conjugate vaccine is used routinely ${ }^{6-10}$. Despite the positive effect obtained with the widespread use of this vaccine and also the growing trend toward the use of meningococcal and pneumococcal conjugate vaccines of specific serogroups or serotypes, these forms of meningitis remain a significant public health problem in poorer countries and regions, particularly among children $^{6,7,9,11-16}$.

In Brazil, bacterial meningitis is common and, as in other developing countries, affects mainly children under the age of 5 years ${ }^{9,11}$. Over the past 4 years, its incidence has been $\sim 4$ cases $/ 100,000$ inhabitants ${ }^{17}$ and the mean fatality for the 1990-2008 period was $19.1 \%^{18}$. After the introduction of the Hib conjugate vaccine, $N$. meningitidis became the 
principal causative agent of bacterial meningitis of known etiology in $\mathrm{Brazil}^{18}$, with the average incidence of meningococcal meningitis being 1.9 cases $/ 100,000$ inhabitants during 2002-2006 ${ }^{19}$. Indeed, this form of bacterial meningitis is the most relevant for public health, since only this form may present as a major epidemic.

In $2008,34 \%$ of the confirmed cases of meningitis in the State of Bahia consisted of the bacterial form of the disease, and meningococcal meningitis, which is endemic in this state, accounted for $30.6 \%$ of cases. Therefore, following the introduction of the Hib vaccine in the second semester of 1999, N. meningitidis (meningococcus) became the most common agent in these infections ${ }^{20}$. During 2000-2008, the overall average incidence of the meningococcal form of the disease was 1.2 cases/100,000 inhabitants and 3.9 cases $/ 100,000$ in children aged $<5$ years. In Salvador, the capital of the State of Bahia, this indicator was 0.7 cases $/ 100,000$ for the entire population and 5.2 cases $/ 100,000$ for the children younger than 5 years during the same period ${ }^{21}$. The overall fatality rate in the State of Bahia and in the City of Salvador at that same time was 25.4\% and $17.7 \%$, respectively. For children aged $<5$ years and infants aged $<12$ months, the fatality rates in the State of Bahia were $33.8 \%$ and $35.6 \%$, respectively, whereas in Salvador, respective rates of $24.2 \%$ and $30 \%$ were registered for the same age groups ${ }^{21}$. These rates are higher than those found for meningococcal disease in Guatemala of $21.4 \%$ in children aged from 1-59 months $\mathrm{s}^{22}$ and even for the State of Rio de Janeiro from 1987-1994 when the fatality rate was $18.8 \%$ for children aged $<5$ years and $23.6 \%$ for those aged $<12$ months ${ }^{23}$.

Although meningococcal meningitis affects all social classes, its intensity varies according to the different socioeconomic strata of the population, with some authors reporting higher rates associated with precarious living conditions ${ }^{24}$. In practice, living conditions represent a valuable criterion for identifying determinants of epidemiological differences related to the occupation of a geographical social space $^{25}$, since the spatial pattern of a city is also defined by social relationships ${ }^{26}$. Within this perspective, although meningitis is infectious and requires the presence of the microbial agent for it to occur, it is relevant to take the living conditions of the population into consideration when evaluating this disease, since the disease results from a combination of multiple determinants, including social determinants. Since social space represents the level of organization of human life, where physical phenomena, relationships, and interactions among individuals, groups, and sub-populations exclusively occur ${ }^{27}$, the process of its occupation may be considered an inherent part of the determinants of the living conditions ${ }^{28}$. The present study was conducted to describe the time trend and distribution of bacterial meningitis in the population of Salvador and to determine whether there is an association between its spatial variation and the living conditions of the population.

\section{METHODS}

We performed an epidemiological study involving individual and ecological analyses, the latter using the calendar year and information zones (IZs) as units of analysis that consisted of the 95 areas into which the City of Salvador was classified by the Regional Metropolitan Development Company according to socioeconomic criteria of physical infrastructure, administration, and planning, and compatibility with the census sectors defined by the Brazilian Institute of Geography and Statistics (IBGE).
The study population consisted of the residents of the City of Salvador (in 1995 and 2009). The data on meningitis were acquired from the National System of Notifiable Diseases and the database of the Directors of Epidemiological Surveillance of the Department Health of the State of Bahia. Information on the population was obtained from the Brazilian Ministry of Health, while demographic and socioeconomic data were obtained from IBGE (2000).

In the individual analysis, the percentages of bacterial meningitis (in 1995, 2000, 2004, and 2009) were calculated according to gender and age group. Incidence, fatality, and mortality rates (annual mean) for the total population and for each individual age group were calculated for the period 2004-2009.

For the ecological analysis, the temporal evolution of bacterial meningitis was established by constructing trend curves of the annual incidence rates from 1995-2009 and for the principal etiological agents from 2000-2009. To allow spatial analysis, the residential addresses of the confirmed patients with meningitis (2004-2009) were geo-referenced according to IZ by using Google Earth, a publicly available program distributed by Google, and a software program (LOCALIZA) ${ }^{29}$ developed by the Collective Health Institute of the Federal University of Bahia. Next, the incidence and fatality rates for all bacterial forms of meningitis were calculated for each IZ for that period to minimize possible distortions resulting from the small number of cases and deaths from the disease in the various IZs. The spatial distribution pattern of meningitis was identified by inspecting thematic maps constructed using ArcView 3.3 and the spatial statistics module of S-PLUS 6.0 based on the distribution of the crude and adjusted rates of incidence according to IZ, following Freeman-Tukey transformation ${ }^{30}$. Next, the existence of spatial autocorrelation of the incidence rate was evaluated using the global Moran index ${ }^{31}$, after excluding 2 IZs that consisted of islands belonging to the municipality.

To examine the association between the spatial variation in the incidence of bacterial meningitis and living conditions, the methodology of Paim et al. ${ }^{32}$ was adopted to construct a living conditions index (LCI) composed of 5 proxy variables of life conditions: income (proportion of heads of family in permanent private households with a mean monthly income $\leq 2$ minimum salaries); slum (percentage of households within subnormal clusters); education (proportion of literate individuals aged 10-14 years in the population); sanitation (percentage of households with an internal water supply connected to the mains); and agglomeration (ratio of inhabitants per room). Since data on the number of rooms that served as bedrooms were not available per census sector for the year 2000, this final indicator was substituted for the individuals/ room ratio. Nevertheless, data on the number of rooms per home per census sector were also unavailable; therefore, an estimate was made assuming that the proportion of rooms per home in each IZ in 2000 was the same as that registered in 1991 . Three of the indicators (slum, income, and individuals/room) were listed in increasing order, while 2 (education and sanitation) were listed in decreasing order. A score was assigned, starting at 1 , in accordance with the position acquired in this order. The sum of the values of this score resulted in an LCI for each IZ. These were listed in increasing order and grouped into quartiles of relatively homogenous IZs, corresponding to the strata of the population classified as having high, intermediate, low, and very low living conditions, and then represented on a thematic map. For each these strata, the mean annual incidence rate 
of bacterial meningitis and meningococcal disease was calculated for the 2004-2009 period, and the relative risk (RR) at the $95 \%$ confidence interval, taking the highest stratum of living conditions as a reference. Since the existence of spatial autocorrelation was not detected between the incidence rates, spatial linear regression analysis was not required; therefore, the association between the incidence of bacterial meningitis (and meningococcal disease) and the LCI, as well as each one of its component variables, were verified per IZ using simple linear regression performed $(\mathrm{p}<0.05)$ with Stata 9.0. $\mathrm{P}$-values $<0.05$ were considered statistically significant.

\section{Ethics considerations}

The protocol for this study was approved by the Ethics Committee of the Collective Health Institute, Federal University of Bahia, Brazil.

\section{RESULTS}

During 1995-2009, a total of 3,456 cases of bacterial meningitis were confirmed, corresponding to a mean annual incidence rate of 9.1 cases/100,000 inhabitants. This indicator appears to be decreasing, with values dropping from 16.1 cases/100,000 inhabitants in 1995 to 5.8 cases $/ 100,000$ inhabitants from $2006-2008$ and 7.8 cases $/ 100,000$ inhabitants in 2009. There was a decrease in meningococcal disease from 2000-2007, and a trend toward an increase from 2008 onwards. On the other hand, pneumococcal meningitis remained relatively stable over this period, while meningitis due to $H$. influenzae decreased by $94 \%$ (Figure 1). The majority of cases occurred in males, and the risk of the disease was also higher among males, with an incidence of 21.0 cases/100,000 inhabitants in 1995 and 8.9 cases $/ 100,000$ inhabitants in 2004 . The fatality and mortality rates from the bacterial forms of meningitis in this period were $16.7 \%$ and 1.5 cases/100,000 inhabitants, respectively.

Distribution analysis according to age group for this form of meningitis for the years 1995, 2000, 2004, and 2009 shows that the percentage of children aged $<5$ years compared to the total number of cases decreased from $186(51.7 \%)$ cases in 1995 to 62 (26.4\%) cases in 2009, whereas the incidence increased in individuals aged $\geq 20$ years from 57 (15.8\%) in 1995 to 104 (44.3\%) in 2009 .

From 2004-2009, 1,082 cases of these forms of meningitis were confirmed, with an incidence rate of 6.5 cases $/ 100,000$ inhabitants and a mean lethality rate of $17.1 \%$ for this period. In children aged $<5$ years, the incidence rate was 49.5 cases $/ 100,000$ inhabitants and the fatality rate was $18.3 \%$; while for infants aged $<12$ months, the incidence rate was 21.9 cases $/ 100,000$ inhabitants and the fatality rate was $21.2 \%$ (Table 1). N. meningitidis was the principal etiological agent (25.9\%), with an incidence of 1.7 cases/100,000 inhabitants, followed by $S$. pneumoniae ( 0.7 cases/100,000 inhabitants), Mycobacterium tuberculosis (0.2 cases/100,000 inhabitants), and H. influenzae (0.1 cases/100,000 inhabitants). Fatality was highest for M. tuberculosis, with a rate of $51.2 \%$ for the population as a whole and $60 \%$ for children aged $<5$ years, followed by S. pneumoniae ( $31.4 \%$ and $45.5 \%$, respectively), N. meningitidis ( $21.4 \%$ and $25.3 \%$, respectively), and $H$. influenzae ( $20 \%$ and $12.5 \%$, respectively).

Figure 2 describes the distribution of the LCI according to IZs, showing that the highest scores (i.e., poorest life conditions) were found along the east-west axis and in the northern part of the city, indicating poor (scores of 176-256) and very poor (260-352) living

TABLE 1 - Bacterial meningitis: annual number and percentage of cases and deaths. Fatality rate, incidence, and mortality rate (cases per 100,000 inhabitants) by age. Salvador, Brazil, 2004-2009.

\begin{tabular}{|c|c|c|c|c|c|c|c|}
\hline \multirow[b]{2}{*}{ Age (by year) } & \multicolumn{3}{|c|}{ Cases } & \multicolumn{4}{|c|}{ Deaths } \\
\hline & $\mathbf{n}$ & $\%$ & I & $\mathbf{n}$ & $\%$ & FR & MR \\
\hline$<1$ & 132 & 12.2 & 49.5 & 28 & 15.1 & 21.2 & 10.5 \\
\hline $1-4$ & 153 & 15.1 & 15.1 & 26 & 14.1 & 16.0 & 2.4 \\
\hline $5-9$ & 135 & 12.5 & 9.8 & 17 & 9.2 & 12.6 & 1.2 \\
\hline $10-14$ & 90 & 8.3 & 6.3 & 4 & 2.2 & 4.4 & 0.3 \\
\hline $15-19$ & 91 & 8.4 & 5.5 & 8 & 4.3 & 8.8 & 0.5 \\
\hline $20-49$ & 349 & 32.3 & 4.2 & 78 & 42.1 & 22.3 & 0.9 \\
\hline$\geq 50$ & 122 & 11.3 & 4.9 & 24 & 13.0 & 19.7 & 1.0 \\
\hline Total & 1,082 & 100.0 & 6.5 & 185 & 100.0 & 17.1 & 1.1 \\
\hline
\end{tabular}

FR: fatality rate; I: incidence; MR: mortality rate.

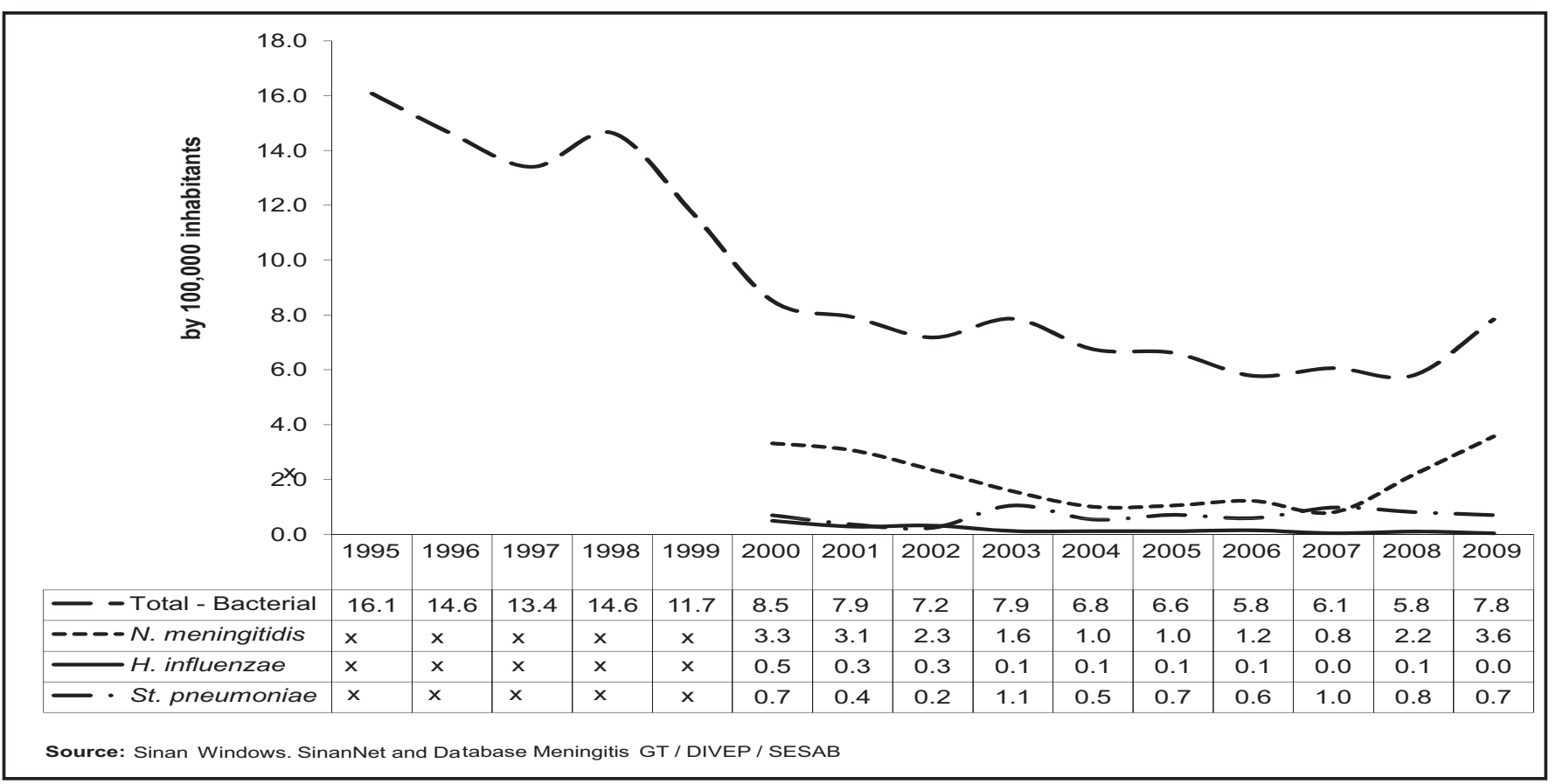

FIGURE 1 - Incidence of bacterial meningitis - total and main etiologies - according to year of occurrence. Salvador, Brazil, $1995-2009$. 


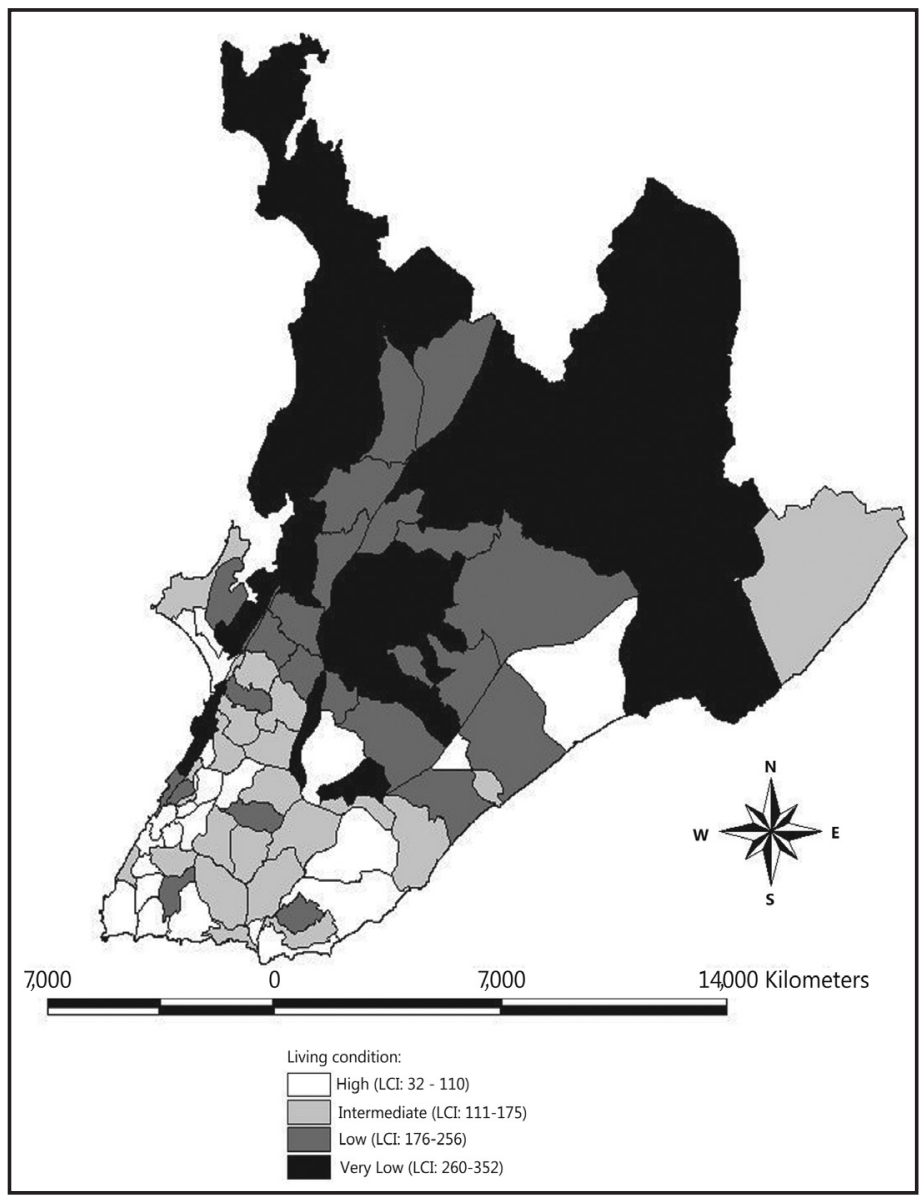

FIGURE 2 - Intra-urban areas of Salvador, Brazil (information zones) according to the living conditions index (LCI), 2000.

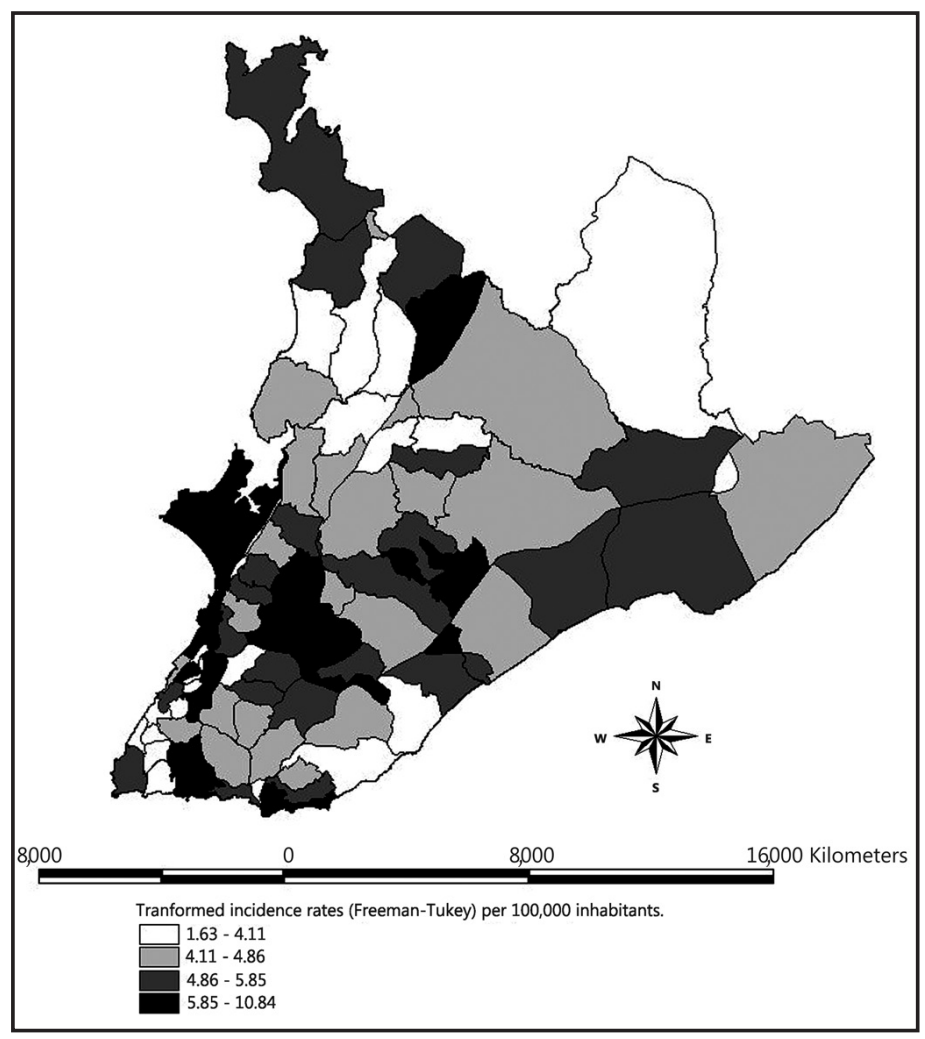

FIGURE 3 - Spatial distribution of incidence rates (transformed) of bacterial meningitis according to information zones. Salvador, Brazil, 2004-2009. conditions. On the other hand, the lowest scores (32-110) were concentrated principally in the southern portion, whereas areas with intermediate life conditions (111-175) were found in some IZs in the southern, eastern, and western regions of the city.

In general, the spatial distribution of bacterial meningitis (according to IZ) in Salvador for the 2004-2009 period revealed higher incidence rates (adjusted) (5.85-10.84 cases/100,000 inhabitants) in areas situated in the center and west, in 3 IZs in the south, and $1 \mathrm{IZ}$ in the north of the city, while intermediate rates (4.11-4.86 cases $/ 100,000$ inhabitants) were more prevalent along the north-south axis (Figure 3). This same distribution pattern was also found for the crude rates. The lower adjusted rates appear in many areas of the city. The global Moran index for this distribution was $0.03524(\mathrm{p}=0.454)$, indicating an absence of an autocorrelation for these rates between neighboring areas.

Comparison of Figures $\mathbf{2}$ and $\mathbf{3}$ shows that the majority of the areas in which the incidence rates of bacterial meningitis were higher were found in the IZ strata with intermediate or high life conditions. However, no statistically significant difference was found in the RR for the occurrence of bacterial meningitis between the 4 life condition strata; the same observation was made for the meningococcal form of the disease (Table 2). With respect to distribution by IZ, simple linear regression analysis also failed to find any association between the incidence of bacterial meningitis and LCI or with the variables that constituted this index. A similar finding was seen for meningococcal disease; however, a weak but statistically significant association was found between fatality and this index $(\mathrm{p}<0.005)$.

TABLE 2 - Incidence of bacterial meningitis and meningococcal disease (cases per 100,000 inhabitants) and the relative risk by strata of living conditions. Salvador, Brazil, 2004-2009.

\begin{tabular}{|c|c|c|c|c|c|c|c|c|}
\hline \multirow{3}{*}{$\begin{array}{l}\text { Living conditions } \\
\text { High }\end{array}$} & \multicolumn{4}{|c|}{ Bacterial meningitis } & \multicolumn{4}{|c|}{ Meningococcal disease } \\
\hline & \multirow{2}{*}{$\frac{\mathbf{I}}{6.5}$} & \multirow{2}{*}{$\frac{\mathbf{R R}}{-}$} & \multicolumn{2}{|c|}{$\mathrm{CI}_{95 \%}$} & \multirow{2}{*}{$\begin{array}{l}\text { I } \\
-\end{array}$} & \multirow{2}{*}{$\frac{\mathbf{R R}}{-}$} & \multicolumn{2}{|c|}{$\mathrm{CI}_{\mathbf{9 5} \%}$} \\
\hline & & & 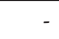 & 1.61 & & & - & - \\
\hline Intermediate & 6.3 & 0.97 & 0.78 & 1.22 & 0.97 & 0.60 & 0.37 & 0.99 \\
\hline Low & 7.3 & 1.12 & 0.91 & 1.38 & 1.96 & 1.21 & 0.80 & 1.85 \\
\hline Very low & 5.9 & 0.91 & 0.74 & 1.11 & 1.72 & 1.07 & 0.71 & 1.60 \\
\hline
\end{tabular}

I: incidence; RR: relative risk; $\mathbf{C I}_{\mathbf{9 5} \%}$ : $95 \%$ confidence interval.

\section{DISCUSSION}

The decreasing incidence of bacterial meningitis found in Salvador during 1995-2009 may have been the result of a reduction in the incidence of the forms of the disease caused by H. influenzae and in the stable rates of meningitis caused by S. pneumoniae, since the incidence of the meningococcal form was found to have increased in 2008 and 2009, and preliminary data for 2010 suggest a continuation of this trend toward an increase ${ }^{33}$. Since bacterial meningitis involves various etiological agents with different clinical and epidemiological characteristics, epidemiological studies are not traditionally used to consider these infections as a group, and that includes the studies designed and conducted in Brazil. Nevertheless, a similar trend to that found in this study for these types of meningitis was also reported in Santo Domingo, Dominican Republic, albeit only for children aged $<5$ years and for the period 1998-2004, with the exception of meningococcal meningitis, which remained stable throughout this period'. 
Despite the decline, the incidence levels of these infections remain high in Salvador, principally in children aged $<5$ years, with an incidence of almost 22 cases / 100,000 inhabitants in this age group, a lower rate than that registered in Romania (33 cases/100,000 inhabitants) $)^{34}$, but higher than that recorded in Santo Domingo, Dominican Republic (16 cases/100,000 inhabitants) ${ }^{9}$. As reported in previous studies ${ }^{2,13,22,35}$, males have a higher risk of being infected by bacterial meningitis in Salvador.

The significant reduction in the group of bacterial meningitis and particularly in those cases caused by $H$. influenzae may be the result of the epidemiological impact of the broad vaccine coverage (from 2 months to 5 years of age) against Hib that has been implemented in Brazil ${ }^{14,36}$, a phenomenon also registered in other countries ${ }^{9,37,38}$.

Few studies have examined the morbidity and mortality from meningitis caused by $M$. tuberculosis, despite the fact that fatality is always highest with this form of the disease, as confirmed in the present study in which a recent time period (2000-2009) was evaluated. These results showed that, although biomedical development has led to a reduction in its incidence through the implementation of intradermal BCG vaccination ${ }^{39}$, the therapeutic advances available for this form of tuberculosis have so far been shown to be insufficient in preventing death.

Fatality due to meningococcal infection has also been very high. In the overall population of Salvador, fatality reached 21.4\%, higher than that found in the City of São Paulo ${ }^{24}$ in 2000 (17.6\%) and more than twice the rate considered acceptable (10\%) as a function of the efficacy and accessibility of available antimicrobial drugs. Unfortunately, almost half of the children aged $<5$ years who acquire the disease evolve to death. This adverse outcome may be the result of a greater difficulty in accessing healthcare in Salvador, since meningococcal disease begins suddenly and severely, with a rapid progression. Therefore, any delay in reaching diagnosis and in receiving medical attention may be crucial and may lead to an unfavorable outcome. Furthermore, it should be emphasized that it is in the most underprivileged sectors of society that the majority of deaths occur, strengthening the hypothesis that the difficulty experienced by these populations in receiving prompt medical attention constitutes an important factor for this outcome, since fatality is a valuable indicator of medical care in meningococcal disease ${ }^{24}$.

Considering that, in general, the intensity of the occurrence of bacterial meningitis is associated with poverty ${ }^{40,41}$, the absence of a specific spatial distribution pattern of its incidence in Salvador may be suggestive of the existence of under-registration, possibly as a function of the difficulties confronted in reaching an etiological diagnosis due to the indiscriminate use of antimicrobial drugs and the fragility of the network of laboratories, among other factors. The lack of a spatial autocorrelation with respect to the incidence of this form of meningitis is unsurprising, since the majority of the etiological agents involved have a limited capability of resistance in the environment, particularly meningococcus. Therefore, contagion occurs between an infected individual and a susceptible one, with no interference from the environment.

Although recognizing the need for caution in interpreting the analyses of secondary data, especially because of the possibility of incomplete data, duplications, incongruences, and underregistration, the results of this study (the first to evaluate the spatial distribution of bacterial meningitis and its relationship with living conditions in the city of Salvador) may be considered valid, since an effort was made to minimize some of these problems by conducting a thorough review of the databases and by clustering data from a series of cases registered over a 6-year period.

Despite the impact obtained both in Salvador and in Brazil as a whole following implementation of the broad vaccine coverage against some bacterial forms of meningitis, these infections unfortunately continue to constitute a very serious public health problem in this city, not only because they represent significant costs from outpatient medical care, hospitalizations, and often intensive care but also principally because of the premature deaths and the temporary and permanent sequelae suffered by survivors. It is obvious that the inclusion of new immunogens such as the meningitis $\mathrm{C}$ conjugate vaccine and the 10 -valent pneumococcal conjugate vaccine in the national immunization program ${ }^{42}$ will further reduce the incidence of these infections. Nevertheless, since the findings of this study highlight the poor quality of medical care provided to the population of this city, it is important to adopt initiatives aimed at improving the efficacy and effectiveness of the preventive, prophylactic, diagnostic, and therapeutic measures that have already been adopted, and principally to increase access and improve the speed with which infected patients are dealt with in order to prevent avoidable deaths.

\section{CONFLICT OF INTEREST}

The authors declare that there is no conflict of interest.

\section{REFERENCES}

1. World Health Organization. The Organization [Internet]. Washington DC: World Health Organization; 2004. [Cited 2010 Jan 20] Available from: http://www. who.int/healthinfo/global_burden_disease/Dth6_2008_20090416.xls/.

2. Theodoridou MN, Vasilopoulou VA, Atsali EE, Pangalis AM, Mostrou GJ, Syriopoulou VP, et al. Meningitis registry of hospitalized cases in children: epidemiological patterns of acute bacterial meningitis throughout a 32-year period. BMC Infect Dis 2007; 7:101.

3. Howitz M, Christiansen AH, Harboe ZB, Molbak K. Surveillance of bacterial meningitis in children under 2 y of age in Denmark, 1997-2006. Scand J Infect Dis 2008; 40:881-887.

4. Nigrovic LE, Kuppermann N, Malley R. Children with bacterial meningitis presenting to the emergency department during the pneumococcal conjugate vaccine era. Acad Emerg Med 2008; 15:522-528.

5. Tique V, Alvis N, Parodi R, Bustos A, Mattar S. Meningitis Agudas en Córdoba Colombia 2002 - 2004. Rev Salud Publica 2006; 8 (supl 1): 33-46.

6. World Health Organization. Immunization. The Organization [Internet] Washington DC: World Health Organization; 2009. [Cited 2010 Jan 25] Available from: http://www.who.int/immunization/topics/meningitis/en/.

7. Casado Flores J, Aristeguib J, Liriac CR, Martinónd JM, Péreze CF. Prevalencia de meningitis neumocócica en niños españoles. An Pediatr 2002; 56:583.

8. Sarmento A, Guardiano M, Silva CS, Teixeira ME, Valente CAP. Meningite bacteriana-revisão de dois anos. RNC 2004; 13: 9-15.

9. Lee EH, Corcino M, Moore A, Garib Z, Peña C, Sánchez J, et al. Impact of Haemophilus influenzae tipo $\mathrm{b}$ conjugate vaccine on bacterial meningitis in the Dominican Republic. Rev Panam Salud Publica 2008; 24:161-168.

10. Seuc AH, Pérez A, Dickinson F, Ortiz D, Domínguez E. Carga de la meningitis bacteriana en Cuba, año 2000. Rev Cubana Salud Pública [Internet]. $2008 \mathrm{Abr}$. Jun; [Cited 2012 January 3]; 34(2). Available from: http://scielo.sld.cu/scielo. php?pid=S0864-4662008000200005\&script=sci_arttext/.

11. Mantese OC, Hirano J, Santos IC, Silva VM, Castro E. Perfil etiológico das meningites bacterianas em crianças. J Pediatr 2002; 78:467-474.

12. Sáfadi MAP, Barros AP. Vacinas meningocócicas conjugadas: eficácia e novas combinações. J Pediatr 2006; 82 (supl 3): S35-S44. 
13. Vieira AC, Gomes MC, Rolo Filho M, Eudes Filho J, Bello EJM, Figueiredo RB. Streptococcus pneumoniae: a study of strains isolated from cerebrospinal fluid. J Pediatr 2007; 83:71-78.

14. Miranzi SSC, Moraes SA, Freitas ICM. Impact of the Haemophilus influenzae type $b$ vaccination program on HIB meningitis in Brasil. Cad Saude Publica $2007 ; 23: 1689-1695$

15. Lewis RF, Kisakye A, Gessner BD, Duku C, Odipio JB, Iriso R, et al. Action for child survival: elimination of Haemophilus influenzae type $\mathrm{b}$ meningitis in Uganda. Bull World Health Organ 2008; 86:292-301.

16. Picazo JJ. Management of antibiotic-resistant Streptococcus pneumoniae infections and the use of pneumococcal conjugate vaccines. Clin Microbiol Infect 2009; 15 (supl 3): 4-6.

17. Ministério da Saúde. Meningites [Internet]. Brasília: Ministério da Saúde. [Cited 2011 Jun 8]. Available from: http://dtr2004.saude.gov.br/sinanweb/.

18. Ministério da Saúde. Secretaria de Vigilância em Saúde. Coordenação de Vigilância de Doenças de Transmissão Respiratória e Imunopreveníveis. Situação epidemiológica das meningites bacterianas no Brasil. Reunião nacional de atualização da vigilância das meningites bacterianas. Brasília: Ministério da Saúde; 2008.

19. Ministério da Saúde. Meningite por Haemophilus influenzae. Distribuição de casos confirmados por Unidade Federada, Brasil, 1980-2005. Brasília: Ministério da Saúde. [Cited $2011 \mathrm{Feb} 8$ ]. Available from: http://portal.saude.gov.br/portal/ arquivos/pdf/meningite_haemo_2006.pdf/.

20. Secretaria da Saúde. Diretoria de Vigilância Epidemiológica. Grupo Técnico de Meningites. Bol Epidemiol 2009a; 3:13.

21. Secretaria de Saúde do Estado da Bahia. Diretoria de Vigilância Epidemiológica. Grupo Técnico de Meningites. Salvador: Secretaria da Saúde; 2009b.

22. Dueger El, Asturias EJ, Halsey NA. Culture-and antigen-negative meningitis in Guatemalan children. Rev Panam Salud Publica 2008; 24: 248-255.

23. Gama SGN, Marzochi KBF, Siveira Filho GB. Caracterização epidemiológica da doença meningocócica na área metropolitana do Rio de Janeiro, Brasil, 1976 a 1994. Rev Saude Publica 1997; 31: 254-262.

24. Moraes JC, Barata RB. A doença meningocócica em São Paulo, Brasil, no século XX: características epidemiológicas. Cad Saude Publica 2005; 21:1458-1471.

25. Possas C. Padrões epidemiológicos: uma proposta conceitual. In: Possas C, editor. Epidemiologia e sociedade: heterogeneidade estrutural e saúde no Brasil. São Paulo: Editora Hucitec; 1989. p. 179-234.

26. Santos M. Por uma geografia nova: da crítica da geografia a uma geografia crítica. São Paulo: Editora Hucitec; 1978.
27. Castellanos PL. Epidemiologia, saúde pública, situação de saúde e condições de vida: considerações conceituais. In: Barata RB, editor. Condições de vida e situação de saúde. Saúde Movimento, 4. Rio de Janeiro: Abrasco; 1997.p. 31-76.

28. Santos M. Espaço e método. São Paulo: Nobel; 1985.

29. Barreto FR, Teixeira MG, Costa MCN, Carvalho MS, Barreto ML. Spread pattern of the first dengue epidemic in the city of Salvador, Brazil. BMC Public Health 2008; 8:51.

30. Cressie N, Read TR. Spatial data analysis of regional counts. Biom J 1989; 31:699-719.

31. CliffAD, Ord JK. Spatial process: models and applications. London: Pion; 1981.

32. Paim JS, Silva LM, Costa MC, Prata PR, Lessa I. Desigualdades na situação de saúde do município de Salvador e relações com as condições de vida. Rev Ci Med Biol 2003; 2:30-39.

33. Secretaria de Saúde do Estado da Bahia . Diretoria de Vigilância Epidemiológica. Grupo Técnico de Meningites. Bol Epidemiol 2011; 5:1.

34. Luca V, Gessner BD, Luca C, Turcu T, Rugina S, Rugina C, et al. Incidence and etiological agents of bacterial meningitis among children $<5$ years of age in two districts of Romania. Eur J Clin Microbiol Infect Dis 2004; 23: 523-528.

35. Barata RCB. Epidemia de doença meningocócica, 1970/1977: aparecimento e disseminação do processo epidêmico. Rev Saude Publica 1988; 22:16-24.

36. Miranzi SSC, Moraes SA, Freitas ICM. Tendência das meningites por Haemophilus influenzae tipo b no Brasil, em menores de 5 anos, no período de 1983 a 2002. Rev Soc Bras Med Trop 2006; 39: 473-477.

37. Agudelo CI, Munoz N, De La Hoz F. Evaluación rápida del impacto de la vacuna contra Haemophilus influenzae serotipo b en Colombia. Pan Am J Public Health 2008; 181-183.

38. Zhou F, Bisgard KM, Yusuf HR, Deuson RR, Bath SK, Murphy TV. Impact of universal Haemophilus influenzae type $b$ vaccination starting at 2 months of age in the United States: An economic analysis. Pediatrics 2002; 110: 653-661.

39. Barreto ML, Pereira SM, Ferreira AA. BCG vaccine: efficacy and indications for vaccination and revaccination. J Pediatr 2006; 82(supl 3): S45-S54.

40. Nery-Guimarães R, Bittencourt LCM, Pastor NVA. Meningites virais e bacterianas no Município do Rio de Janeiro (Brasil): algumas considerações sobre o sistema de informações em saúde e sobre a distribuição da doença no espaço urbano. Rev Saude Publica 1981; 15:379-394.

41. Marzochi KBF, Lopes PFA, Ramos Filho C. Meningoencefalites agudas. Clin Pediatr 1985; 9:9-17.

42. Portaria n. 3.318, de 28 de outubro de 2010. Institui em todo o território nacional, o Calendário Básico de vacinação da Criança, o Calendário do Adolescente e o Calendário do Adulto e Idoso. [Cited 2011 Feb 8] Available from: http://bvsms. saude.gov.br/bvs/saudelegis/gm/2010/prt3318_28_10_2010.html. 